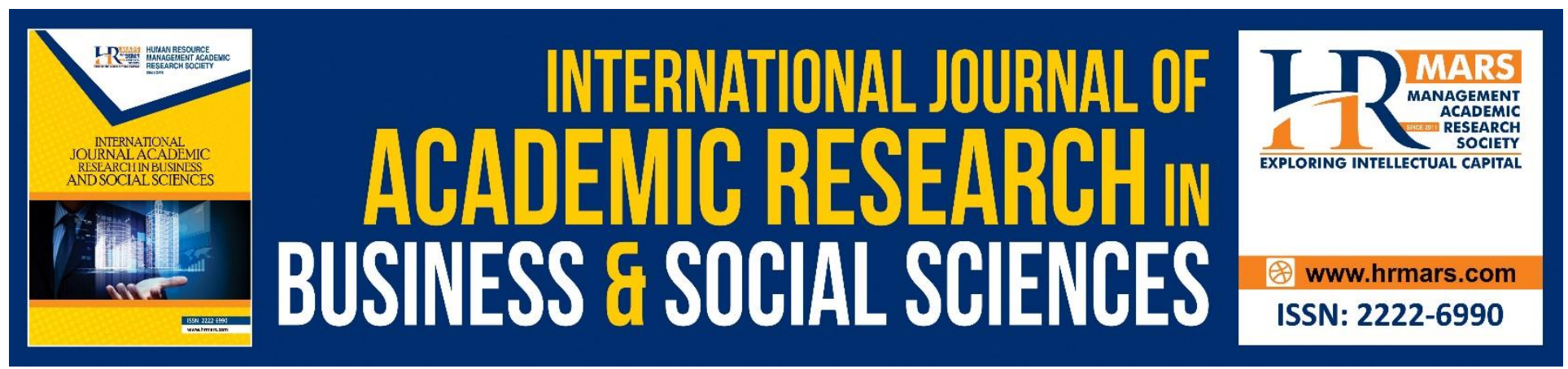

\title{
The Perceived Level of Importance of Competency Constructs for Future Graphic Design Graduates in Malaysia
}

\section{Shaw-Chiang Wong, Muhammad Zaffwan Idris, and Wee-Chuen Tan}

To Link this Article: http://dx.doi.org/10.6007/IJARBSS/v10-i11/7952

DOI:10.6007/IJARBSS/v10-i11/7952

Received: 17 September 2020, Revised: 28 September 2020, Accepted: 23 October 2020

Published Online: 14 November 2020

In-Text Citation: (Wong, Idris, and Tan, 2020)

To Cite this Article: Wong, S-C., Idris, M. Z., and Tan, W.-C. (2020). The Perceived Level of Importance of Competency Constructs for Future Graphic Design Graduates in Malaysia. International Journal of Academic Research in Business and Social Sciences. 10(11), 259-276.

\section{Copyright: (c) 2020 The Author(s)}

Published by Human Resource Management Academic Research Society (www.hrmars.com)

This article is published under the Creative Commons Attribution (CC BY 4.0) license. Anyone may reproduce, distribute, translate and create derivative works of this article (for both commercial and non-commercial purposes), subject to full attribution to the original publication and authors. The full terms of this license may be seen

at: $\underline{\text { http://creativecommons.org/licences/by/4.0/legalcode }}$

Vol. 10, No. 11, 2020, Pg. 259 - 276

http://hrmars.com/index.php/pages/detail/IJARBSS

JOURNAL HOMEPAGE

Full Terms \& Conditions of access and use can be found at http://hrmars.com/index.php/pages/detail/publication-ethics 


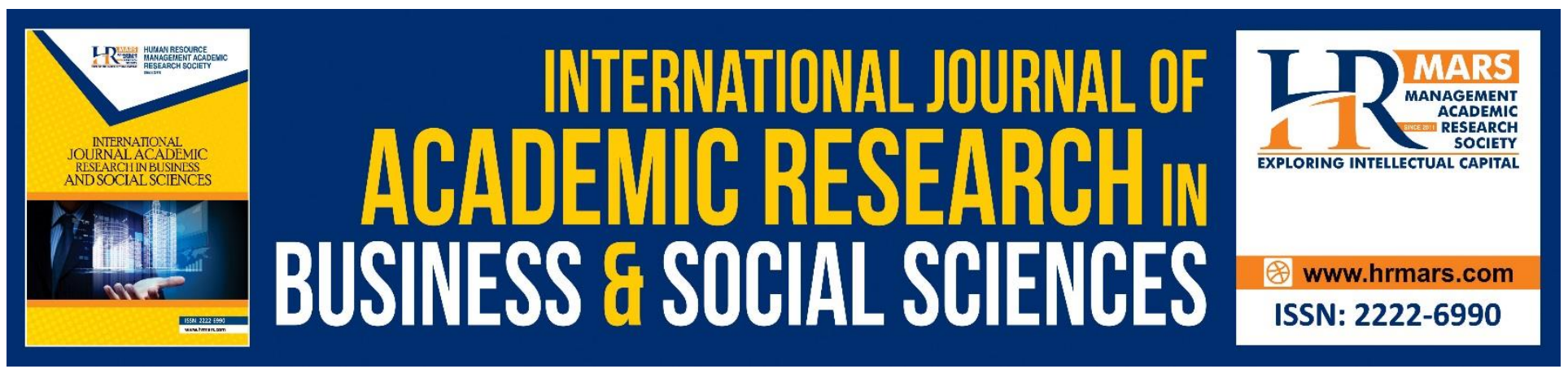

\title{
The Perceived Level of Importance of Competency Constructs for Future Graphic Design Graduates in Malaysia
}

\section{Shaw-Chiang Wong ${ }^{a}$, Muhammad Zaffwan Idris ${ }^{b}$, and Wee-Chuen $\operatorname{Tan}^{\mathrm{a}}$}

${ }^{a}$ Faculty of Art and Design, Raffles University, Johor Bahru, Malaysia; ${ }^{b}$ Faculty of Art, Computing and Creative Industry, Universiti Pendidikan Sultan Idris, Tanjong Malim, Malaysia, Shaw-Chiang Wong, Lecturer, Faculty of Art and Design, Raffles University, Menara Kotaraya, level 9, Unit No: 09-01, Jalan Trus, 80000 Johor Bahru, Johor, MALAYSIA.

Email: wongshawchiang@raffles-university.edu.my

\begin{abstract}
Although a number of studies on identifying the competency constructs required by future graduates for working effectively in the professional practice of graphic design (GD) have been conducted, there is a lack of empirical evidence within the literature showing the ranking of importance of these constructs. Therefore, the study intends to determine the perceived level of importance among GD experts regarding the essential competency constructs for future GD graduates in the context of Malaysia. Survey questionnaire was used to collect data from 19 university-level design academics and 13 industry practitioners. Relative of Importance Index (RII) was used to analyse the data. The top 10 competency constructs in order of their ranked importance as perceived by the experts were: teamwork and leadership skills, project management skills, marketing fundamentals, self-efficacy, advertising design skills, reflective thinking skills, communication skills, industry knowledge, emotional intelligence, and design fundamentals. The results suggested that education of graphic designers must go beyond the conventional scope of technical training to prepare students for the evolving work of design practice.
\end{abstract}

Keywords: Graphic Design Graduates, Design Academics, Industry Practitioners, Competency Constructs, and Malaysia

\section{Introduction}

GD is a relatively young profession as compared to some other professions in the creative field such as architecture and fine arts (Short, 2011). GD was officially considered as a profession during the Industrial Revolution in the $18^{\text {th }}$ century when a line was drawn between fine art and commercial art (Hollis, 1994; Meggs \& Purvis, 2012). The early GD education system was adapted from the vocational training ideology of the Bauhaus in early $20^{\text {th }}$ century. Students are trained to 
INTERNATIONAL JOURNAL OF ACADEMIC RESEARCH IN BUSINESS AND SOCIAL SCIENCES Vol. 10, No. 11, 2020, E-ISSN: 2222-6990 @ 2020 HRMARS

possess good technical ability and formal sensitivity to effectively bring image and text to print in practice (Davis, 2005; Marks, 2015; Swanson, 2004). Hence, the key emphasis of GD profession and education has long been placed on 'the making of things and beautiful things' (American Institute of Graphic Arts (AIGA), 2015b).

However, driven by the growth of information age and knowledge economy, several new areas have been developed to represent the more recent status of GD as a profession and an academic discipline. According to Davis (2005), these areas are: "code of ethics and standards of fair practice; documented history; components of practice devoted exclusively to criticism and research; and the publication of substantive literature, including theoretical and critical discourse" (p. 67). Besides, as the scope of design practice is expanding, graphic designers are found to work more frequently in non-design areas such as business strategy, brand development, innovation management, and service design together with specialists from other disciplines (Davis, 2005). Certainly, graphic designers are required to possess additional skill sets to tackle new challenges in practice successfully (Adu, 2015; Dziobczenski \& Person, 2017; Dziobczenski et al., 2018). Studies (e.g., Chiang et al., 2019) also suggested that term 'GD' can hardly represent the current state of the profession and therefore other more appropriate terms such as 'experience design', 'information design', 'communication design', 'visual communication design' should be used.

The expansion of the scope in contemporary graphic designers' work calls into question the traditional priorities for educating graphic designers (Chiang et al., 2018). This is especially the case when discussing employers' needs and graduates' employability (Kang et al., 2015; Lewis \& Bonollo, 2002). Studies showed that the quality of GD graduates fails to meet the employers' demands (Adu, 2015; Butler, 1995; Debbie, 2011; McCoy, 1997). Many design graduates, including GD, encounter difficulties to secure positions in industry (Naveiro \& Pereira, 2008). The key reason behind this is that GD education has been too slow to catch up to the expanded scope of the practice (Davis, 2015).

Several studies have been done in different countries on identifying the skills, knowledge, abilities, and attributes that should be imparted in GD education for the students to perform effectively in professional practice after graduation (e.g., AIGA, 2017; Bridges, 2013; Dhavarath, 2003; Hsieh et al., 2015). Through conducting in-depth interviews, Adu's (2015) study found out that employers of graphic designers in Ghana tend to hire fresh graduates with additional capabilities, including industry knowledge, changing nature of work, time management, work experience, communication skills, problem-solving, broaden knowledge, technology, collaboration, emotional intelligence, self-respect, self-usefulness, and confidence. Wang (2006) used a three-round modified Delphi technique with design academics and practitioners in Kansas and Missouri. The experts identified 66 key competencies to be considered in the development and implementation of GD related programmes and 20 most essential competencies for employment. These competencies were classified by Wang (2006) into four clusters: design competencies, soft skills, technical competencies, and computer-related competencies. According to Wang (2006), design competencies must be integrated into GD curriculum as they are viewed as highly important for employment by the experts.

Dziobczenski and Person (2017) conducted a rigorous thematic analysis of 1,406 job advertisements to shed light on 'what knowledge and skills are companies referencing in advertising for GD positions' in the United Kingdom. Based on the analysis, they distinguished 26 skills that employers seek from graphic designers. These skills were grouped into four categories: (1.) operational design skills; (2.) process management skills; (3.) technical design skills; and (4.) software skills. In general, the most frequently mentioned skills across the advertisements were functionally 
INTERNATIONAL JOURNAL OF ACADEMIC RESEARCH IN BUSINESS AND SOCIAL SCIENCES Vol. 10, No. 11, 2020, E-ISSN: 2222-6990 @ 2020 HRMARS

related, including: 2D software skills, teamwork skills, project planning and administration skills, creativity, and aesthetic skills, and detailing and production skills.

AIGA (2015a), the oldest, largest, and most prestigious American professional design association in the world had been working closely with Adobe Inc. to predict the future of GD practice. The result uncovered a range of 13 desired competencies that will be required, in various combination, by graphic designers of the future to deal with the emerging trends in design. These competencies are:

1. Ability to create and develop visual response to communication problems, including understanding of hierarchy, typography, aesthetics, composition, and construction of meaningful images.

2. Ability to solve communication problems including identifying the problem, researching, analysis, solution generating, prototyping, user testing and outcome evaluation.

3. Broad understanding of issues related to the cognitive, social, cultural, technological, and economic contexts for design.

4. Ability to respond to audience contexts recognizing physical, cognitive, cultural, and social human factors that shape design decisions.

5. Understanding of and ability to utilize tools and technology.

6. Ability to be flexible, nimble, and dynamic in practice.

7. Management and communication skills necessary to function productively in large interdisciplinary teams and "flat" organizational structures.

8. Understanding of how systems behave and aspects that contribute to sustainable products, strategies, and practices.

9. Ability to construct verbal arguments for solutions that address diverse users / audiences; lifespan issues; and business / organizational operations.

10. Ability to work in a global environment with understanding of cultural preservation.

11. Ability to collaborate productively in large interdisciplinary teams.

12. Understanding of ethics in practice.

13. Understanding of nested items including cause and effect; ability to develop project evaluation criteria that account for audience and context.

According to AIGA (2015a), these competencies should be considered by higher educational institutions (HEIs) when developing and delivering GD curricula to empower the graduates to meet the demands of the future.

This body of literature, in short, suggests that future GD graduates are expected to be multiskilled to begin their professional careers in modern society (Adu, 2015). However, of so many skills, knowledge, and traits that have been previously identified, which should be focused more on the education to best prepare the students for future practice? This question is tricky, and it always serves as a topic of debate among design academics and industry practitioners (Dziobczenski \& Person, 2017). This is the case because, as highlighted by Cheung (2012), that "The purpose of academia is to train up students to become professionals, whereas the design company's purpose is to provide design solutions for profit maximization" (p. 9). As a result, the perceived level of importance of certain competencies is different in between design academics and industry practitioners. Nevertheless, up to the best notice of the researchers of this study, there is a lack of empirical evidence showing the ranking of importance of the competencies required by future GD 
INTERNATIONAL JOURNAL OF ACADEMIC RESEARCH IN BUSINESS AND SOCIAL SCIENCES Vol. 10, No. 11, 2020, E-ISSN: 2222-6990 @ 2020 HRMARS

graduates, specifically in the context of Malaysia. Therefore, the study aims to fill this gap within the literature. Accordingly, the research questions addressed by the study were:

1. What is the ranking of importance of the constructs as perceived by design academics and industry practitioners in Malaysia?

2. Do design academics' perceptions differ from the industry practitioners' perceptions of the competency constructs?

\section{Methodology}

\section{Sample}

This study utilized purposive snowball sampling technique to collect data from various fields of GD academics and industry practitioners in Malaysia. In total, 39 experts were identified to answer the questionnaire comprising competency constructs and their respective items required by GD graduates for effective work performance in the future. The participating experts were asked to rank each item from 1 (not at all important) to 5 (extremely important). Of the distributed questionnaires, 32 were returned, representing $82.1 \%$ of response rate. Table 1 displays the details.

Table 1. Participants' response rate

\begin{tabular}{llll}
\hline Expert group & $\begin{array}{l}\text { Number of } \\
\text { participants }\end{array}$ & $\begin{array}{l}\text { Number of } \\
\text { responses }\end{array}$ & $\begin{array}{l}\text { Percent of response } \\
(\%)\end{array}$ \\
\hline Design academic & 22 & 19 & 86.3 \\
Industry practitioner & 17 & 13 & 76.4 \\
\hline Total & 39 & 32 & 82.1 \\
\hline
\end{tabular}

\section{Instrumentation}

A new questionnaire was developed the researchers to answer the research questions addressed by the study. The questionnaire consisted of both demographic information and survey instrument. Aside from demographic data of the respondents (current position, area of specialization, years of experience, age, gender, and academic qualification), the questionnaire comprised 134 items seeking information on 33 competency constructs. These constructs were grouped further in five competence components, i.e., cognitive competence, functional competence, personal competence, ethical competence, and meta-competencies, as proposed by Cheetham and Chivers $(1996,1998)$. The constructs and items were identified through extensive reading on the related literature within the past 10 years and consultation with prominent experts in the field.

The questionnaire was reviewed by two experts prior to distribution. They were recruited based on their knowledge and experience in GD education and industry. The survey instrument was examined for ease of use and clarity, and to ensure that the items were relevant for data collection and analysis, free of construction problems, logically arranged and grouped, and grammatically correct.

\section{Data Analysis}

Relative importance index (RII) was used to analyse the collected data to determine the ranking of importance of the competency constructs. The RII is calculated using the equation (Somiah et al., 2015; Muhwezi et al., 2014): 
INTERNATIONAL JOURNAL OF ACADEMIC RESEARCH IN BUSINESS AND SOCIAL SCIENCES Vol. 10, No. 11, 2020, E-ISSN: 2222-6990 @ 2020 HRMARS

$$
\mathrm{RII}=\frac{\sum \mathrm{w}}{\mathrm{A} * \mathrm{~N}}(0 \leq \mathrm{RII} \leq 1)
$$

Where:

$W=$ weight given to each item by the respondents and ranges from 1 to 5 ;

$A=$ the highest weight; and

$\mathrm{N}=$ the total number of respondents.

The group index was calculated by taking the average of constructs in each group. MannWhitney $U$ Test was performed to examine if there is a significant difference between the perceptions of design academics and industry practitioners on the level of importance of the constructs. The data was analysed using Statistical Package for the Social Sciences (SPSS) version 21.

\section{Results}

\section{Demographic Information}

The results of the descriptive analysis of the design academics suggested that $(n=13,68.4 \%)$ of them were working at the private HEls, while $(n=6,31.6 \%)$ were working at the public HEls. The majority of them were teaching visual communication design $(n=12,63.2 \%)$. This was followed by digital and interactive design $(n=5,26.3 \%)$ and advertising design $(n=2,10.5 \%) .(n=13,68.7 \%)$ of the participants were having more than 10 years of teaching experience in relevant programmes in the field of education, and most of them were master's degree holders ( $n=10,52.6 \%)$. $(n=13,68.4 \%)$ of the participants were males, while $(n=6,31.6 \%)$ were females. Details are depicted in Table 2.

Table 2. Design academics' demographic information ( $N=19)$

\begin{tabular}{lll}
\hline Variable & Frequency & Percent (\%) \\
\hline Working at & 13 & 68.4 \\
\hline Private higher educational institution & 6 & 31.6 \\
Public higher educational institution & & \\
\hline Programme taught & 12 & 63.2 \\
\hline Visual communication design & 2 & 10.5 \\
Advertising design & 5 & 26.3 \\
Digital and interactive design & & \\
\hline Current position & 4 & 21.1 \\
\hline Head of school or department & 7 & 36.8 \\
Head of programme & 8 & 42.1 \\
Lecturer & & \\
\hline Total years of teaching experience & 3 & 15.8 \\
\hline$<5$ years & 3 & 15.8 \\
$6-10$ years & 5 & 26.3 \\
11- 15 years & 5 & 26.3 \\
$16-20$ years & 3 & 15.8 \\
$>$ 20 years & & \\
\hline Highest academic qualification & 2 & 10.5 \\
\hline Bachelor's degree & 10 & 26.8 \\
Master's degree & 7 & \\
Doctorate degree & & \\
\hline
\end{tabular}


INTERNATIONAL JOURNAL OF ACADEMIC RESEARCH IN BUSINESS AND SOCIAL SCIENCES Vol. 10, No. 11, 2020, E-ISSN: 2222-6990 @ 2020 HRMARS

The results of the descriptive analysis of industry practitioners indicated that majority of them ( $n=6,46.2 \%$ ) were currently working at GD studio. The participants specialize in a wide variety of different areas in $\mathrm{GD}$, ranging from advertising design $(n=1,7.7 \%)$, brand identity design and consultancy $(n=4,30.8 \%)$, graphic communication design $(n=3,23.1 \%)$, illustration $(n=1,7.7 \%)$, digital and interactive design $(n=2,15.3 \%)$, to motion graphics or videography $(n=1,7.7 \%)$ and environmental GD ( $n=1,7.7 \%)$. $(n=10,69.2 \%)$ of them were creative, art or design directors. $(n=3$, $23.1 \%$ ) of the participants had more than 20 years of practical working experience. Table 3 illustrates the details.

Table 3. Industry practitioners' demographic information ( $\mathrm{N}=13)$

\begin{tabular}{lll}
\hline Variable & Frequency & Percent (\%) \\
\hline Working at & 1 & 7.7 \\
\hline Advertising agency & 6 & 46.2 \\
Design studio & 4 & 30.8 \\
Brand consultation company & 2 & 15.3 \\
Production house & & \\
\hline Area of specialization & 1 & 7.7 \\
\hline Advertising design & 4 & 30.8 \\
Brand identity design and consultancy & 3 & 23.1 \\
Graphic communication design & 1 & 7.7 \\
Illustration & 2 & 15.3 \\
Digital and interactive design & 1 & 7.7 \\
Motion graphics or videography & 1 & 7.7 \\
Environmental graphic design & & \\
\hline Current position & 10 & 69.2 \\
\hline Creative, art or design director & 1 & 7.7 \\
Design consultant & 3 & 23.1 \\
Designer & & \\
\hline Total years of working experience & 2 & 15.3 \\
\hline $6-10$ years & 3 & 23.1 \\
11- 15 years & 5 & 38.5 \\
16- 20 years & 3 & 23.1 \\
$>$ 20 years & 5 & \\
\hline Highest academic qualification & 5.5 \\
\hline Diploma & & \\
Bachelor's degree & & \\
\hline
\end{tabular}

\section{Ranking of Importance of Competency Constructs}

RII was used to analyse the collected data from the experts to determine the degree of importance of the constructs. The RII for all the items was calculated. The overall index was calculated by taking the average of constructs in each key component. The details are tabulated in Table 4. 
INTERNATIONAL JOURNAL OF ACADEMIC RESEARCH IN BUSINESS AND SOCIAL SCIENCES Vol. 10, No. 11, 2020, E-ISSN: 2222-6990 @ 2020 HRMARS

Table 4. Order of importance of constructs in each key component

\begin{tabular}{|c|c|c|}
\hline Constructs & RII & Internal Rank \\
\hline \multicolumn{3}{|l|}{ Cognitive Competence } \\
\hline Design Fundamentals & 0.840 & 3 \\
\hline Art and Design History & 0.571 & 7 \\
\hline Industry Knowledge & 0.853 & 2 \\
\hline Contextual Awareness & 0.835 & 4 \\
\hline Multidisciplinary Knowledge & 0.740 & 6 \\
\hline Business Fundamentals & 0.777 & 5 \\
\hline Marketing Fundamentals & 0.877 & 1 \\
\hline Overall & 0.784 & 5 \\
\hline \multicolumn{3}{|l|}{ Functional Competence } \\
\hline Technical Design Skills & 0.806 & 6 \\
\hline Conceptual Design Skills & 0.823 & 5 \\
\hline User-centred Design Skills & 0.713 & 9 \\
\hline Data Visualisation Skills & 0.700 & 10 \\
\hline Interactive Design Skills & 0.831 & 3 \\
\hline Advertising Design Skills & 0.867 & 2 \\
\hline Software Skills & 0.739 & 7 \\
\hline Graphic Print Production Skills & 0.828 & 4 \\
\hline Project Management Skills & 0.881 & 1 \\
\hline Research Skills & 0.716 & 8 \\
\hline Overall & 0.790 & 4 \\
\hline \multicolumn{3}{|l|}{ Personal Competence } \\
\hline Aesthetic and Visual Sensitivity & 0.823 & 4 \\
\hline Self-driven & 0.816 & 5 \\
\hline Adaptability and Flexibility & 0.838 & 3 \\
\hline Emotional Intelligence & 0.842 & 2 \\
\hline Interpersonal Skills & 0.775 & 6 \\
\hline Self-efficacy & 0.876 & 1 \\
\hline Overall & 0.828 & 2 \\
\hline \multicolumn{3}{|l|}{ Values / Ethical Competence } \\
\hline Professional Behaviours & 0.836 & 1 \\
\hline Professional Expertise & 0.813 & 2 \\
\hline Professional Value & 0.784 & 3 \\
\hline Overall & 0.811 & 3 \\
\hline \multicolumn{3}{|l|}{ Meta-competencies } \\
\hline Creative Thinking Skills & 0.831 & 6 \\
\hline Problem Solving Skills & 0.838 & 4 \\
\hline Design Thinking Skills & 0.792 & 7 \\
\hline Critical Thinking Skills & 0.834 & 5 \\
\hline Reflective Thinking Skills & 0.858 & 2 \\
\hline Communication Skills & 0.854 & 3 \\
\hline Teamwork and Leadership Skills & 0.889 & 1 \\
\hline Overall & 0.842 & 1 \\
\hline
\end{tabular}


INTERNATIONAL JOURNAL OF ACADEMIC RESEARCH IN BUSINESS AND SOCIAL SCIENCES Vol. 10, No. 11, 2020, E-ISSN: 2222-6990 @ 2020 HRMARS

Based on the findings, marketing fundamentals (RII=0.877) was found to be the most important construct for cognitive competence component. It was followed by industry knowledge (RII=0.853), design fundamentals ( $R I=0.840)$, and contextual awareness (RII=0.835). Business fundamentals ( $R I=0.777)$, multidisciplinary knowledge ( $R I=0.740)$, and art and design history ( $R I I=0.540)$ were in the last three places of ranking.

The GD experts in Malaysia considered the top three most important constructs for functional competence component were: project management skills (RII=0.881), advertising design skills (RII=0.867), and interactive design skills (RII=0.831); for personal competence component were: selfefficacy ( $R I=0.876)$, emotional intelligence ( $R I I=0.842)$, and self-driven ( $R I I=0.838$ ); and for metacompetencies component were: teamwork and leadership skills (RII=0.889), reflective thinking skills ( $R I I=0.858)$, and communication skills (RII=0.854). For values / ethical competence component, the experts thought that professional behaviours $(R I=0.836)$ was more important than professional values ( $R I I=0.784)$ and professional expertise ( $R I I=0.813)$.

As shown also from Table 4, meta-competencies appeared to be the most important competence component with overall RII $=0.842$. These results were followed by personal competence component with overall RII $=0.828$, ethical competence component with overall RII $=0.811$, and functional competence component with overall RII $=0.790$. On top of that, cognitive competence component was in the last ranking with overall RII=0.784.

Finally, the overall ranking of importance of all constructs across five key competence components were: teamwork and leadership (RII=0.889), project management skills (RII=0.881), marketing fundamentals ( $R I I=0.877$ ), self-efficacy ( $\mathrm{RII}=0.876$ ), advertising design skills (RII=0.867), interactive design skills (RII=0.865), reflective thinking skills (RII=0.858), communication skills (RII=0.854), industry knowledge (RII=0.853), and professional behaviours (RII=0.851). These constructs were among the top ten most important competency constructs that must be possessed by future GD graduates for effective work performance.

\section{Differences between Design Academics and Practitioners on the Level of Importance of the Constructs}

Mann-Whitney U Test was employed to compare differences between design academics and practitioners on the level of importance of all investigated constructs. With reference to Table 5, the greatest difference of mean rank between academics and practitioners was professional expertise (8.42). This was followed by conceptual design skills (7.65), marketing fundamentals (7.32), contextual awareness (6.28), and graphic print production skills (6.03). Overall, the average of mean rank for design academics was 19.74 , while for practitioners was 11.77 , which showed a difference of 7.97. Table 5 displays the mean rank and sum of ranks of each construct for these two groups.

Table 5. Mean rank and sum of ranks of each construct for academics and practitioners

\begin{tabular}{lllll}
\hline & Group & N & Mean Rank & Sum of Ranks \\
\hline Design Fundamentals & Design academics & 19 & 17.13 & 325.50 \\
& Practitioners & 13 & 15.58 & 202.50 \\
\cline { 2 - 3 } & Total & 32 & & \\
\hline \multirow{2}{*}{ Art and Design History } & Design academics & 19 & 18.42 & 350.00 \\
& Practitioners & 13 & 13.69 & 178.00 \\
\cline { 2 - 3 } & Total & 32 & & \\
\hline
\end{tabular}


INTERNATIONAL JOURNAL OF ACADEMIC RESEARCH IN BUSINESS AND SOCIAL SCIENCES Vol. 10, No. 11, 2020, E-ISSN: 2222-6990 @ 2020 HRMARS

\begin{tabular}{|c|c|c|c|c|}
\hline \multirow[t]{3}{*}{ Industry Knowledge } & Design academics & 19 & 16.29 & 309.50 \\
\hline & Practitioners & 13 & 16.81 & 218.50 \\
\hline & Total & 32 & & \\
\hline \multirow[t]{3}{*}{ Contextual Awareness } & Design academics & 19 & 19.05 & 362.00 \\
\hline & Practitioners & 13 & 12.77 & 166.00 \\
\hline & Total & 32 & & \\
\hline \multirow[t]{3}{*}{ Multidisciplinary Knowledge } & Design academics & 19 & 15.87 & 301.50 \\
\hline & Practitioners & 13 & 17.42 & 226.50 \\
\hline & Total & 32 & & \\
\hline \multirow[t]{3}{*}{ Business Fundamentals } & Design academics & 19 & 16.76 & 318.50 \\
\hline & Practitioners & 13 & 16.12 & 209.50 \\
\hline & Total & 32 & & \\
\hline \multirow[t]{3}{*}{ Marketing Fundamentals } & Design academics & 19 & 19.47 & 370.00 \\
\hline & Practitioners & 13 & 12.15 & 158.00 \\
\hline & Total & 32 & & \\
\hline \multirow[t]{3}{*}{ Technical Design Skills } & Design academics & 19 & 16.87 & 320.50 \\
\hline & Practitioners & 13 & 15.96 & 207.50 \\
\hline & Total & 32 & & \\
\hline \multirow[t]{3}{*}{ Conceptual Design Skills } & Design academics & 19 & 19.61 & 372.50 \\
\hline & Practitioners & 13 & 11.96 & 155.50 \\
\hline & Total & 32 & & \\
\hline \multirow[t]{3}{*}{ User-centred Design Skills } & Design academics & 19 & 17.53 & 333.00 \\
\hline & Practitioners & 13 & 15.00 & 195.00 \\
\hline & Total & 32 & & \\
\hline \multirow[t]{3}{*}{ Data Visualization Skills } & Design academics & 19 & 18.74 & 356.00 \\
\hline & Practitioners & 13 & 13.23 & 172.00 \\
\hline & Total & 32 & & \\
\hline \multirow[t]{3}{*}{ Interactive Design Skills } & Design academics & 19 & 18.55 & 352.50 \\
\hline & Practitioners & 13 & 13.50 & 175.50 \\
\hline & Total & 32 & & \\
\hline \multirow[t]{3}{*}{ Advertising Design Skills } & Design academics & 19 & 18.32 & 348.00 \\
\hline & Practitioners & 13 & 13.85 & 180.00 \\
\hline & Total & 32 & & \\
\hline \multirow[t]{3}{*}{ Software Skills } & Design academics & 19 & 16.13 & 221.50 \\
\hline & Practitioners & 13 & 17.04 & 306.50 \\
\hline & Total & 32 & & \\
\hline Graphic Print Production & Design academics & 19 & 18.95 & 360.00 \\
\hline \multirow[t]{2}{*}{ Skills } & Practitioners & 13 & 12.92 & 168.00 \\
\hline & Total & 32 & & \\
\hline \multirow[t]{3}{*}{ Project Management Skills } & Design academics & 19 & 17.89 & 340.00 \\
\hline & Practitioners & 13 & 14.46 & 188.00 \\
\hline & Total & 32 & & \\
\hline Research Skills & Design academics & 19 & 18.55 & 352.50 \\
\hline
\end{tabular}


INTERNATIONAL JOURNAL OF ACADEMIC RESEARCH IN BUSINESS AND SOCIAL SCIENCES Vol. 10, No. 11, 2020, E-ISSN: 2222-6990 @ 2020 HRMARS

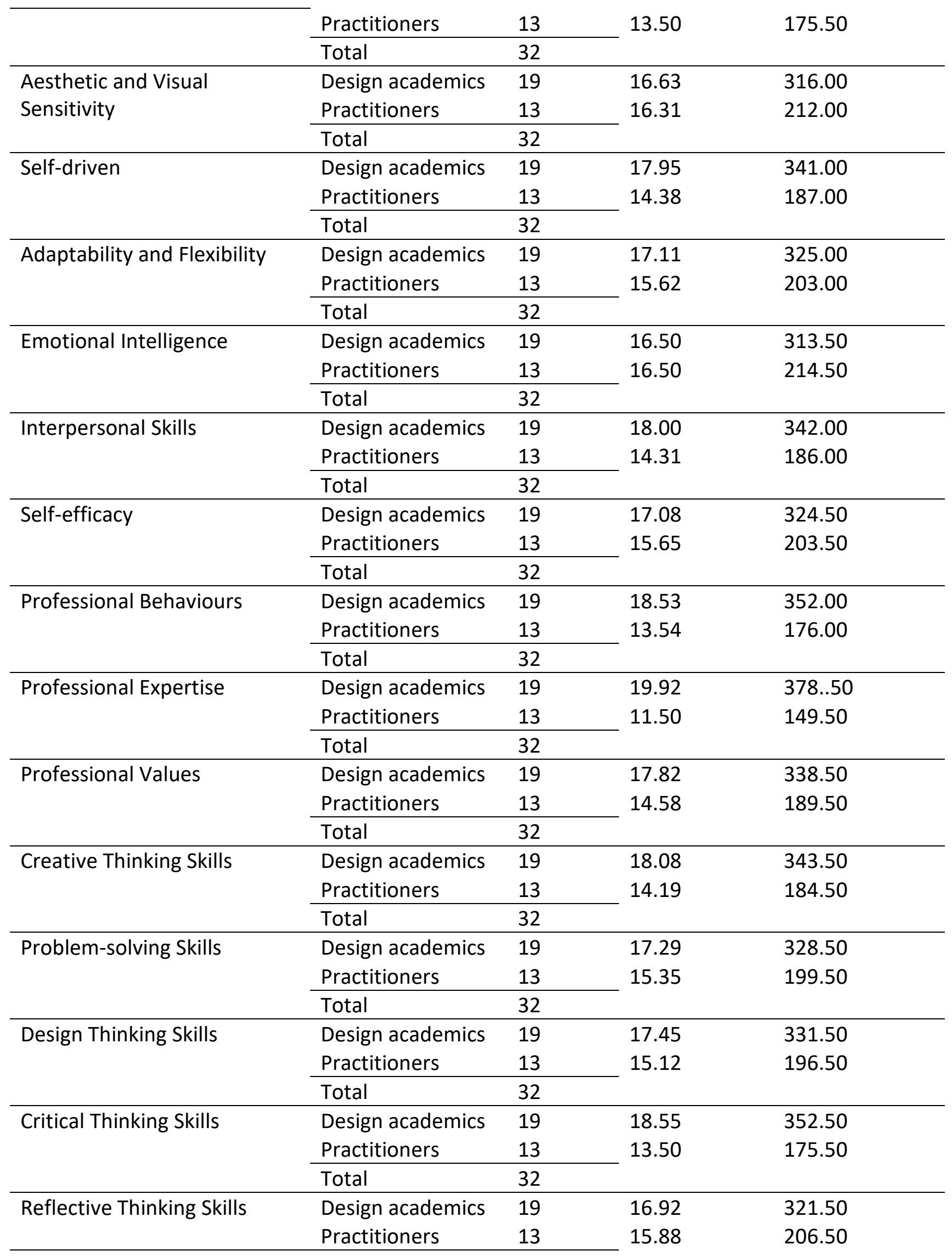


INTERNATIONAL JOURNAL OF ACADEMIC RESEARCH IN BUSINESS AND SOCIAL SCIENCES Vol. 10, No. 11, 2020, E-ISSN: 2222-6990 @ 2020 HRMARS

\begin{tabular}{|c|c|c|c|c|}
\hline & Total & 32 & & \\
\hline \multirow[t]{3}{*}{ Communication Skills } & Design academics & 19 & 18.03 & 342.50 \\
\hline & Practitioners & 13 & \multirow[t]{2}{*}{14.27} & \multirow[t]{2}{*}{185.50} \\
\hline & Total & 32 & & \\
\hline Teamwork and Leadership & Design academics & 19 & 16.29 & 309.50 \\
\hline \multirow{2}{*}{ Skills } & Practitioners & 13 & \multirow{2}{*}{16.81} & \multirow{2}{*}{218.50} \\
\hline & Total & 32 & & \\
\hline \multirow[t]{3}{*}{ Overall } & Design academics & 19 & 19.74 & 375.00 \\
\hline & Practitioners & 13 & \multirow[t]{2}{*}{11.77} & \multirow[t]{2}{*}{153.00} \\
\hline & Total & 32 & & \\
\hline
\end{tabular}

With reference to Table 6, the obtained significance values of contextual awareness (.039), marketing fundamentals (.015), conceptual design skills (.017), and professional expertise (.009) were less than .05. Such findings indicated that academics and practitioners differed in their perceptions on the level of importance in these four constructs. Finally, the overall significance value obtained was .018. Therefore, it can be concluded that there is a significant difference between design academics and practitioners on the perceived level of importance of the constructs measured in this study.

Table 6. Test statistics ${ }^{\text {a }}$ of Mann-Whitney U Test

\begin{tabular}{|c|c|c|c|c|c|}
\hline & $\begin{array}{l}\text { Mann- } \\
\text { Whitney } \\
\text { U }\end{array}$ & $\begin{array}{l}\text { Wilcoxon } \\
\text { W }\end{array}$ & Z & $\begin{array}{l}\text { Asymp. Sig. } \\
\text { (2-tailed) }\end{array}$ & $\begin{array}{l}\text { Exact Sig. } \\
{[2 *(1 \text {-tailed }} \\
\text { Sig.)] }\end{array}$ \\
\hline Design Fundamentals & 111.500 & 202.500 & -.552 & .581 & $.650^{b}$ \\
\hline Art and Design History & 87.000 & 178.000 & -1.460 & .144 & $.170^{\mathrm{b}}$ \\
\hline Industry Knowledge & 119.500 & 309.500 & -.168 & .866 & $.880^{\mathrm{b}}$ \\
\hline Contextual Awareness & 75.000 & 166.000 & -2.065 & .039 & $.065^{b}$ \\
\hline Multidisciplinary Knowledge & 111.500 & 301.500 & -.555 & .579 & $.650^{\mathrm{b}}$ \\
\hline Business Fundamentals & 118.500 & 209.500 & -.221 & .825 & $.850^{b}$ \\
\hline Marketing Fundamentals & 67.000 & 158.000 & -2.432 & .015 & $.030^{\mathrm{b}}$ \\
\hline Technical Design Skills & 116.500 & 207.500 & -.290 & .772 & $.791^{b}$ \\
\hline Conceptual Design Skills & 64.500 & 155.500 & -2.390 & .017 & $.022^{b}$ \\
\hline User-centred Design Skills & 104.000 & 195.000 & -.812 & .417 & $.472^{b}$ \\
\hline Data Visualization Skills & 81.000 & 172.000 & -1.740 & .082 & $.108^{b}$ \\
\hline Interactive Design Skills & 84.500 & 175.500 & -1.562 & .118 & $.136^{\mathrm{b}}$ \\
\hline Advertising Design Skills & 89.000 & 180.000 & -1.528 & .127 & $.195^{b}$ \\
\hline Software Skills & 116.500 & 306.500 & -.293 & .769 & $.791^{b}$ \\
\hline $\begin{array}{l}\text { Graphic Print Production } \\
\text { Skills }\end{array}$ & 77.000 & 168.000 & -1.852 & .064 & $.077^{b}$ \\
\hline Project Management Skills & 97.000 & 188.000 & -1.141 & .254 & $.323^{b}$ \\
\hline Research Skills & 84.500 & 175.500 & -1.570 & .117 & $.136^{\mathrm{b}}$ \\
\hline $\begin{array}{l}\text { Aesthetic and Visual } \\
\text { Sensitivity }\end{array}$ & 121.000 & 212.000 & -.133 & .894 & $.940^{b}$ \\
\hline Self-driven & 96.000 & 187.000 & -1.136 & .256 & $.305^{b}$ \\
\hline
\end{tabular}


INTERNATIONAL JOURNAL OF ACADEMIC RESEARCH IN BUSINESS AND SOCIAL SCIENCES Vol. 10, No. 11, 2020, E-ISSN: 2222-6990 @ 2020 HRMARS

\begin{tabular}{llllll} 
Adaptability and Flexibility & 112.000 & 203.000 & -.488 & .625 & $.677^{\mathrm{b}}$ \\
Emotional Intelligence & 123.500 & 214.500 & -.000 & 1.000 & $1.000^{\mathrm{b}}$ \\
Interpersonal Skills & 95.000 & 186.000 & -1.236 & .217 & $.287^{\mathrm{b}}$ \\
Self-efficacy & 112.500 & 203.500 & -.482 & .630 & $.677^{\mathrm{b}}$ \\
Professional Behaviours & 85.000 & 176.000 & -1.782 & .075 & $.147^{\mathrm{b}}$ \\
Professional Expertise & 58.500 & 149.500 & -2.682 & .009 & $.011^{\mathrm{b}}$ \\
Professional Values & 98.500 & 189.500 & -1.029 & .303 & $.343^{\mathrm{b}}$ \\
Creative Thinking Skills & 93.500 & 184.500 & -1.344 & .179 & $.254^{\mathrm{b}}$ \\
Problem-solving Skills & 108.500 & 199.500 & -.651 & .515 & $.570^{\mathrm{b}}$ \\
Design Thinking Skills & 105.500 & 196.500 & -.730 & .465 & $.495^{\mathrm{b}}$ \\
Critical Thinking Skills & 84.500 & 175.500 & -1.602 & .109 & $.136^{\mathrm{b}}$ \\
Reflective Thinking Skills & 115.500 & 206.500 & -.333 & .739 & $.762^{\mathrm{b}}$ \\
Communication Skills & 94.500 & 185.500 & -1.315 & .188 & $.270^{\mathrm{b}}$ \\
Teamwork and Leadership & 119.500 & 309.500 & -.164 & .869 & $.880^{\mathrm{b}}$ \\
Overall & 62.000 & 153.000 & -2.361 & .018 & $.018^{\mathrm{b}}$ \\
\hline
\end{tabular}

a. Grouping variable: group

b. Not corrected for ties

\section{Discussion}

The top 10 competency constructs in order of their ranked importance as perceived by the design academics and industry practitioners involved in the study were: teamwork and leadership skills, project management skills, marketing fundamentals, self-efficacy, advertising design skills, reflective thinking skills, communication skills, industry knowledge, emotional intelligence, and design fundamentals. In addition, based on the findings, meta-competencies appeared to be the most important competence component and followed by personal competence component. Metacompetencies refer to those generic and overarching 'soft-qualities' that are able to support the acquisition and development of other competencies (Brown, 1993; Cheetham \& Chivers, 1996, 1998), while personal competence covers those social behaviours, desires, psychological impulses or emotions displayed by individuals in work-related situations (Spencer \& Spencer, 1993). These findings suggested that while 'fundamental' design skills and knowledge for form-making will still be relevant in the future, they have become relatively less important in the employment market as compared to some generic skills and personal traits. To develop and possess these traits and generic skills will favor university graduates in their job seeking process as they are prioritized by a collective of prominent experts in the field of GD. The study believes that GD graduates will experience a more autonomous career if they are properly trained and prepared for these competencies.

Furthermore, the findings also indicated that the role of designers is changing as a result of the changing context for practice. Instead of focusing on 'making beautiful things', GD will be assumed to play a more 'managerial' and 'strategic' role in areas such as business strategy, innovation management, and service design in the future job market (Davis, 2005). This could be the reason why teamwork and leadership skills, project management skills, self-efficacy, reflective thinking skills, communication skills, and emotional intelligence were ranked in the top 10 most important competency constructs for future GD graduates to obtain. Similar findings and insights could also be found in previous studies in Ghana (e.g., Adu, 2015), Finland (e.g., Dziobczenski et al., 2018), and United Kingdom (e.g., Dziobczenski \& Person, 2017) that graphic designers' role and responsibilities 
are becoming more complex, and therefore the students need to be inculcated with additional skills and abilities to gain a competitive edge after graduation. It is believed that with these additional skills and abilities, the graduates are able to draw on experience and knowledge from a wide range of disciplines in the process of design, anticipate the problems at various scales, propose sustainable and ethically sound solutions, identify effective means to reach the targeted audiences, and create information that can stimulate and sustain people's attention (AIGA, 2015b).

The findings also revealed that of the 33 constructs measured in the study, the bottom five lowest rankings were software skills, research skills, user-centred design skills, data visualization skills, and art and design history. To some extent, it is no surprise that art and design history was ranked the lowest because, as what had been argued by Heller (2005), that the value of art and design history knowledge has long been underappreciated in modern GD education and practice, and it is always overshadowed by other practical competencies. However, according to several studies and literature (e.g., AIGA, 2015a, 2017; Davis \& Littlejohn, 2017; Dziobczenski et al., 2018; Muratovski, 2016; Walker, 2017), research skills, user-centred design skills, data visualization skills are considered as highly important for designers to deal effectively with emerging trends in design, but in the current study, they were ranked at the bottom of the lists by the experts. Furthermore, previous studies in the United Kingdom (e.g., Dziobczenski \& Person, 2017) and Brazil (e.g., Dziobczenski \& Galeotti, 2017) suggested that software skills was one of the most highly demanded skills by design academics and practitioners. In other words, a small part of the results of this study was inconsistent with the findings of some studies from different regions.

Overall, the results also revealed that there was a significant difference between design academics and industry practitioners on the perceived level of importance for the constructs measured in this study. The major difference showed in the results was the discrepancy in marketing fundamentals, contextual awareness, conceptual design skills, and professional expertise. Nevertheless, these constructs were ranked at third (3), fourteenth (14), nineteenth (19), and twentieth-second (22) place respectively, which were considered relatively higher than some other constructs in the lists.

\section{Implications of the Study}

Both theoretical and practical implications could be drawn based on the findings of the study. Theoretically, the results of this study have contributed valuable empirical insights into the literature in GD field. They can serve as a springboard for studies on future design education and practice in the context of Malaysia. Practically, the findings are useful for various local stakeholders. GD programme providers are encouraged to reexamine their programme and curriculum structures with reference to the findings to enhance the employability of their graduates. Design academics are encouraged to extend the scope of teaching. Apart from technical design skills, they need to shape their students more holistically from various perspectives to prepare them for additional competencies. However, this requires further study on how those required competencies can be effectively transferred to the students. Therefore, regulatory bodies such as the Malaysian Qualifications Agency, Malaysia Design Council, and Graphic Design Association in Malaysia are encouraged to introduce enrichment workshops for design academics so that they are better enabled to inculcate required competencies across their educational practices. Besides, students are encouraged to take the initiative to discuss with lecturers to work out a mutually agreeable strategy to further strengthen their level of competency in a holistic and integrated manner. To promote lifelong learning, students can take the 
INTERNATIONAL JOURNAL OF ACADEMIC RESEARCH IN BUSINESS AND SOCIAL SCIENCES Vol. 10, No. 11, 2020, E-ISSN: 2222-6990 @ 2020 HRMARS

initiative to update themselves with the latest knowledge to accommodate changes in the world. Certainly, these require facilitation from lecturers. Finally, with reference to the findings, industry practitioners are encouraged to share the responsibilities to facilitate the learning of fresh graduates. This is particular important, as pointed out by Cheung (2012), that "the real problem only occurs when graduates are unable to learn because the workplace does not offer a safe [encouraging] environment for learning or the graduates are not expected to learn in certain working condition" ( $p$. 5).

\section{Limitations and Recommendations}

There are several limitations of this study need to be addressed in future research. First, the number of respondents was small. Only $32 \mathrm{GD}$ experts in Malaysia were involved in the study. Further studies with a larger number of respondents could be conducted to provide a better picture on the perceived level of importance of competency constructs for future GD graduates in Malaysia. Second, the questionnaire used in the current study was developed based on extensive literature review and consultation with prominent experts, rather than using a validated survey instrument. Therefore, future studies could validate the factor structure and psychometric properties of the competency scales.

\section{Conclusion}

Eraut (1994) noted that "the first two or three years after qualifying are probably the most influential in developing the particular personalized pattern of practice of every professional acquires" (p.11). However, the key challenge in these few years involves "different types of discourse and epistemologies" (Eraut, 2007, p.116). This means that education and industry practice value different types knowledge and skills: while the former focuses more on theoretical frameworks, publication, and research-based materials, the latter prioritizes mainly on the ability to make appropriate decisions to achieve desired outcomes with the limited budget given (Cheung, 2012). As a result, university graduates suffer from a 'learning gap' when they enter the job market (Boshuizen, 2003). This phenomenon also happens in GD discipline (Cheung, 2016; Debbie, 2011; McCoy, 1997). To close this gap, it is important for design academics and practitioners to come to an agreement in terms of what should be prioritized in the education to best prepared the graduates for future practice. Although the findings reached to a conclusion that overall there was a significant difference between two parties on the perceived level of importance for the competency constructs investigated in this study, it is critical for both parties to keep their doors open for communication to ensure the fit between graduate labour market supply and demand.

The findings also indicated that there is a shift of focus with regards to the competencies required by GD graduates in the future employment market. Of the top 10 most important competency constructs as perceived by design academics and practitioners who involved in the study, only advertising design skills and design fundamentals belong to the typical scope of GD training or practice. In other words, non-design related, generic, and personal skills are highly valued by the experts. On the other hand, there is a need for an in-depth qualitative investigation to find out how academics and practitioners in Malaysia perceive the usefulness of research skills, data visualization skills, user-centred design skills, and art and design history in future design practice.

As a conclusion, the study suggests that the providers of GD programme, the authorities who prepare the curriculum, persons who implement the curriculum, individuals who work as graphic 
INTERNATIONAL JOURNAL OF ACADEMIC RESEARCH IN BUSINESS AND SOCIAL SCIENCES Vol. 10, No. 11, 2020, E-ISSN: 2222-6990 @ 2020 HRMARS

designers, and employers who hire graphic designers in Malaysia to work together to close the 'learning gap' of GD graduates. Efforts from various stakeholders are needed to ensure that the university students will graduate with the most needed skills and abilities to face the ever-changing world.

\section{References}

Adu, A. (2015). Graduate employability: The link between design education and the graphic design industry. Kwame Nkkrumah University of Science and Technology, Kumasi, Ghana.

American Institute of Graphic Design (AIGA). (2015a). Designer of 2015 Competencies. Retrieved October 1, 2017, from http://www.aiga.org/designer-of-2015-competencies/

American Institute of Graphic Design (AIGA). (2015b). Designer of 2015 Trends. Retrieved October 1, 2017, from http://www.aiga.org/designer-of-2015-trends

American Institute of Graphic Design (AIGA). (2017). AIGA Designer 2025. Retrieved February 15, 2018, from https://educators.aiga.org/wp-content/uploads/2017/08/DESIGNER-2025SUMMARY.pdf.

Boshuizen (2003). Expertise development: how to bridge the gap between school and work. Inaugural address. Open University of the Netherlands.

Bridges, A. W. (2013). Identification of perceived 21st century graphic design skills, content knowledge, and tools needed in an effective university-level graphic design program. ProQuest Dissertations and Theses. Retrieved from https://search.proquest.com/docview/1429501618?accountid=29391

Brown, R. B. (1993). Meta-Competence: A Recipe for Reframing the Competence Debate. Personnel Review, 22(6), 25-36. https://doi.org/10.1108/EL-01-2017-0019

Butler, J. (1995). The process for effective graphic design curriculum development. University of Wisconsin-Madison.

Cheetham, G., \& Chivers, G. (1996). Towards a holistic model of numeracy competence. Jorrunal of European Industrial Training, 20(5), 20-30. https://doi.org/10.1108/03090599610119692

Cheetham, G., \& Chivers, G. (1998). The reflective (and competent) practitioner: A model of professional competence which seeks to harmonise the reflective practitioner and competence-based approaches. Journal of European Industrial Training, 22(7), 267-276. https://doi.org/10.1108/03090599810230678

Cheung, B. P. S. (2012). Double 'Blind Spots' of the academia and design industry. Hong Kong.

Cheung, B. P. S. (2016). Professional graphic design knowledge in Hong Kong: From graduate to professional. Communication Design, 4(1-2), 21-40. https://doi.org/10.1080/20557132.2016.1275476

Chiang, W. S., Idris, M. Z., \& Chuen, T. W. (2019). Is graphic design being taken seriously as a profession? Journal of Arts and Social Sciences, 3(1), 1-9.

Chiang, W. S., Idris, M. Z., \& Chuen, T. W. (2018). What makes an undergraduate graphic design education valuable? Journal of Education and Social Sciences, 11(1), 73-82.

Davis, M. (2005). Raising the bar for higher education. In S. Heller (Ed.), The education of a graphic designer (2nd ed., pp. 13-18). New York: Allworth Press.

Davis, M. (2015). Interdisciplinarity and the education of the design generalist. In S. Heller (Ed.), The education of a graphic designer (3rd ed., pp. 20-29). New York: Allworth Press.

Davis, M. \& Littlejohn, D. (2017). Accountability for anticipating design outcomes. Retrieved February 
INTERNATIONAL JOURNAL OF ACADEMIC RESEARCH IN BUSINESS AND SOCIAL SCIENCES

Vol. 10, No. 11, 2020, E-ISSN: 2222-6990 @ 2020 HRMARS

12, 2019, from American Institute of Graphic Arts (AIGA) website: https://www.aiga.org/aigadesign-futures/accountability-for-anticipating-design-outcomes/

Debbie, G. S. S. (2011). A nation's visual language: Nation branding and the visual identity of contemporary malaysia. Nottingham Trent University.

Dharavath, H. (2003). Importance of technical competencies in the graphic communications technology curriculum as perceived by the graphic communications industry and educators. Journal of Industrial Technology, 19(2), 1-7.

Dziobczenski, P. R. N., \& Galeotti, A. A. R. (2017). Preparing design students for the market: an initial investigation on the required knowledge and skills for graphic designers in Brazil. The Design Journal, 20(sup1), S1241-S1249. https://doi.org/10.1080/14606925.2017.1352653

Dziobczenski, P. R. N., \& Person, O. (2017). Graphic designer wanted: A document analysis of the described skill set of graphic designers in job advertisements from the United Kingdom. International Journal of Design, 11(2), 41-55.

Dziobczenski, P. R. N., Person, O., \& Meriläinen, S. (2018). Designing career paths in graphic design: A document analysis of job advertisements for graphic design positions in Finland. The Design Journal, 21(3), 349-370. https://doi.org/10.1080/14606925.2018.1444874

Eraut (1994). Developing professional knowledge and Competence. London: Falmer Press.

Eraut (2007). Early Career Learning at Work and its Implications for Universities. In Entwistle N. \& Tomlinson P. (Eds), Student Learning and University Teaching, British Journal of Educational Psychology, Monograph Series. 1(1), 113-133.

Heller, Steven. (2005). The education of a graphic designer. In Choice Reviews Online (2nd ed., Vol. 43). New York: Allworth Press.

Hollis, R. (1994). Graphic design: A concise history. London: Thames \& Hudson Ltd.

Hsieh, S.F., Guan, S.S., \& Wu, C. L. (2010). The study on competency of graduating students being major in graphic design. The International Journal of Learning, 17(9), 389-401.

Kang, H. J., Chung, K. W., \& Nam, K. Y. (2015). A competence model for design managers: A case study of middle managers in Korea. International Journal of Design, 9(2), 109-127.

Lewis, W. P., \& Bonollo, E. (2002). An analysis of professional skills in design: Implications for education and research. Design Studies, 23(4), 385-406. https://doi.org/10.1016/S0142694X(02)00003-0

Marks, A. (2015). A design core for the twenty-first century. In S. Heller (Ed.), The education of a graphic designer (3rd ed., pp. 17-19). New York: Allworth Press.

McCoy, K. (1997). Education and professionalism or what's wrong with graphic design education. In How We Learn What We Learn Conference. New York.

Meggs, P. B. \& Purvis, A. W. (2012). Meggs' history of graphic design (5th ed.). John Wiley \& Sons, Inc.

Muhwezi, L., Acai, J., \& Otim, G. (2014). An assessment of the factors causing delays on building construction projects in Uganda. Construction Engineering and Management, 3(1), 13-23. https://doi.org/10.5923/j.ijcem.20140301.02

Muratovski, G. (2016). Research for designers: A guide to methods and practice. California: SAGE Publications Inc.

Naveiro, R.M. \& Pereira, R.c. (2008). Design education in Brazil. Design Education, 29, 304-312.

Short, D. J. R. (2011). The consummate curriculum for the undergraduate graphic design student in the United States. Savannah College of Art and Design. 
INTERNATIONAL JOURNAL OF ACADEMIC RESEARCH IN BUSINESS AND SOCIAL SCIENCES Vol. 10, No. 11, 2020, E-ISSN: 2222-6990 @ 2020 HRMARS

Somiah, M. K., \& Aidoo, I. (2015). Relative importance analysis of factors influencing unauthorized siting of residential buildings in the Metropolis of Ghana. Journal of Building Construction and Planning Research, 3, 117-126. https://doi.org/10.4236/jbcpr.2015.33012

Spencer, L. M. \& Spencer, S. M. (1993). Competence at work: Models for superior performance. New York: John Wiley \& Sons, Inc.

Swanson, G. (2004). Graphic design education as a liberal art: Design and knowledge in the university and the "Real World." Design Issues, 10(1), 53-63.

Walker, S. (2017). Research in Graphic Design. Design Journal, 20(5), 549-559. https://doi.org/10.1080/14606925.2017.1347416

Wang, S.-Y. (2006). Identification of the significant competencies in graphic design. University of Missouri-Columbia. 